\title{
Distribution and Abundance of Kelp in the Alaskan Beaufort Sea near Prudhoe Bay
}

\author{
M. BUSDOSH, ${ }^{1}$ C.L. BEEHLER, ${ }^{2}$ G.A. ROBILLIARD, ${ }^{3}$ and K.R TARBOX ${ }^{4}$
}

\begin{abstract}
Seventeen stations on five transects near Prudhoe Bay were quantitatively sampled for kelp. The easternmost transect was located along the fringe of the Boulder Patch, an area of cobbles and boulders supporting a dense kelp community. The transects progressed westwards for 26 $\mathrm{km}$. Low densities of Laminaria solidungula and $L$. saccharina were found throughout the area. Approximately one-half of the specimens were attached, usually to a pebble or shell buried in the sand-silt substrate. Kelp was most abundant in depths of 4-7 m. No density gradient from the Boulder Patch was found within the study area. Kelp may exist over additional areas of the Beaufort Sea in sufficient numbers to affect faunal diversity and biomass.
\end{abstract}

Key words: kelp, Laminaria solidungula, Laminaria saccharina, Boulder Patch

RÉSUMÉ. Des échantillons furent prélevés à dix-sept stations sur cinq lignes de sectionnement près de la baie Prudhoe afin d'y déterminer la quantité de varech. La section la plus à l'est était située le long du "Boulder Patch", un terrain couvert de grosses pierres et de galets et supportant une dense communauté de varech. Les lignes de sectionnement continuaient vers l'ouest sur une distance de $26 \mathrm{~km}$. Des quantités peu Elevées de Laminaria solidungula et de $L$. saccharina furent trouvées partout dans la région. Environ la moitié des spécimens étaient rattachés à quelque chose, d'habitude à des pierres ou des coquilles enterrées dans le substrat de sable et de vase. Le varech apparaissait en quantité plus abondante à une profondeur d'entre 4 et $7 \mathrm{~m}$. Aucune différence de densité dans le "Boulder Patch" ne fut perçue dans l'aire d'étude. Il est possible que le varech existe dans d'autres régions de la mer de Beaufort dans des quantités pouvant toucher la diversité de la faune et la biomasse.

Mots clés: varech, Laminaria solidungula, Laminaria saccharina, Boulder Patch

Traduit pour le journal par Maurice Guibord.

\section{INTRODUCTION}

Most interest in kelp in the Alaskan Arctic has centered on the Boulder Patch, an area of cobbles and boulders located east of Prudhoe Bay in Stefansson Sound. These cobbles and boulders support a diverse assemblage of organisms. The area has been discussed in the scientific literature (Dunton et al., 1982; Dunton and Schonberg, 1979, 1980), popular magazines (Dunton, 1979) and regulatory documents (Bureau of Land Management, 1979). The vast majority of the coastal Beaufort Sea does not have a rocky substrate, however, but one characterized by silt and sand. Although gravel makes up the substrate around the bases of several of the barrier islands (Beehler $e t$ al., 1979a, 1979b), the overlying sediment covering most of Prudhoe Bay and nearby coastal waters consists primarily of fine silt $(21 \%)$, silt (16\%), very fine sand $(20 \%)$ and fine sand (28\%) (Chin et al., 1979).

The benthic algal communities of the Canadian Arctic become increasingly smaller, less widely distributed, and less diverse the further west they occur (Lee, 1973). This author also noted the exceptional occurrence of drift and in situ growth of several species on clay and silt bottoms in calm bays of arctic Canada. These bays all have low temperatures, low salinities, and freshwater inflows, conditions present offshore of Prudhoe Bay. In a more recent study, Lee (1980) noted that interspersed pebbles or shells could allow kelp growth on soft substrates.

Mohr et al. (1957) mapped the known locations of kelp along the Beaufort Sea. Broad (1978) and Dunton et al. (1982) reported locations of macrophytes encountered during nearshore and littoral investigations in the Alaskan Arctic. During intensive oceanographic and fisheries studies, Chin et al. (1979) observed pieces of macrophytes at 1-3 m depths and whole plants at 5-7 m, and Tarbox and Spight (1979) trawled kelp pieces from 3-5 $\mathrm{m}$ and whole plants from 5-8 $\mathrm{m}$ in the Prudhoe Bay area, which lacks hard substrate.

This study was designed to describe the abundance and distribution of kelp in the non-unique areas, the common areas with sand and silt substrates. The study area (Fig. 1) included the area offshore of Prudhoe Bay between the west end of Stump Island and the fringes of the Boulder Patch. In 1981-82 the dock west of Prudhoe Bay was extended north to a point east of station 2-4.

\section{METHODS AND MATERIALS}

Surveys were performed during periods of ice cover and open water. During the period of ice cover in March and April 1979, kelp were identified and counted by divers at six locations between stations 2-3 and 2-4 (Fig. 1).

Each survey area was quantified by stretching a $10-\mathrm{m}$ rope horizontally against the bottom of the ice and away from the entry hole. At the entry hole $(0 \mathrm{~m})$, midpoint $(5 \mathrm{~m})$ and end of the rope $(10 \mathrm{~m})$, brightly colored and weighted lines were attached that hung to the ocean floor. Swimming a circle, the diver farthest from the entry hole kept the horizontal rope taut and counted phaeophytes between the vertical lines hanging $5 \mathrm{~m}$ and $10 \mathrm{~m}$ from the entry hole. The second diver counted

\footnotetext{
'Affinis, 12622 Acadia Way, Building AG, Lakeside, California 92040, U.S.A.

${ }^{2}$ Department of Physics, University of California, Santa Barbara, California 93106, U.S.A.

${ }^{3}$ Woodward-Clyde Consultants, 100 Pringle Avenue, Walnut Creek, California 94590, U.S.A.

"Alaska Department of Fish and Game, Soldotna, Alaska 99669, U.S.A.
} 


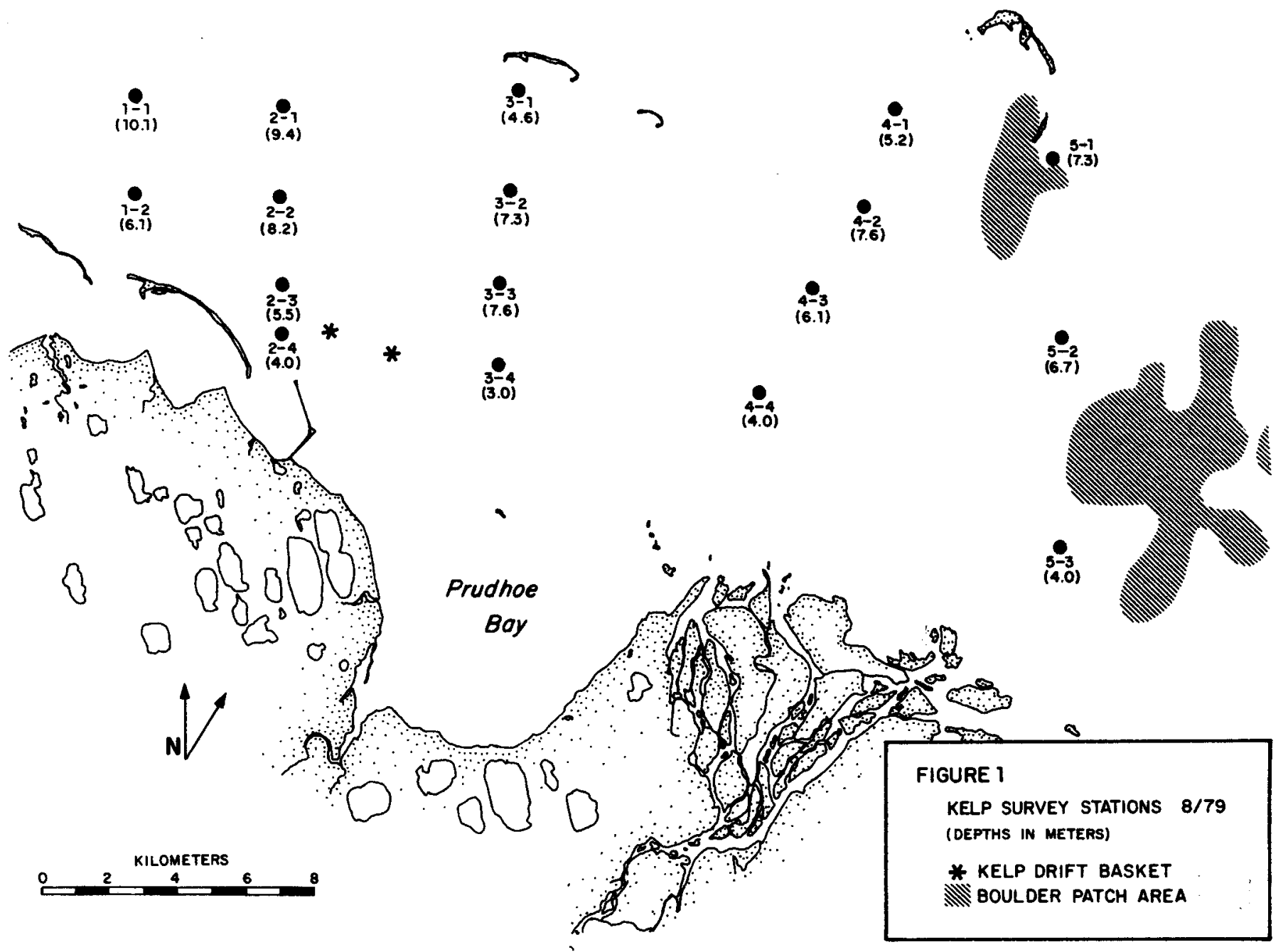

FIG. I. Study area with locations of kelp survey stations.

plants between the $0 \mathrm{~m}$ and $5 \mathrm{~m}$ vertical lines. At the completion of a circle, a surface tender let out 10 additional metres on the horizontal line. Divers then swam a $20 \mathrm{~m}$ circle, counting plants between the $10-20 \mathrm{~m}$ circumferences. Each survey covered $1256 \mathrm{~m}^{2}$. Exceptional water clarity made this survey method possible. Areas of dense plant cover, called patches, were estimated. Four patches were collected in toto with a beam trawl. Two divers and a surface tender pulled a 505-micron, square-mesh beam trawl with a 1.8-m-wide leadline through the kelp patches. Divers pushed plants, fauna and substrate into the net. The plants were washed, identified, total lengths measured and the completeness (having blade, stipe and holdfast) of each phaeophyte was determined. Specimens were preserved in $3 \%$ buffered formalin.

In August, with no ice cover, a survey was conducted to document the phaeophyte species composition over a much larger area than could be sampled in the winter survey. Seventeen stations arranged in five parallel transects oriented north to south were surveyed for phaeophytes (Fig. 1). Station depth ranged from 3-10.1 m. At each station, Laminaria solidungula, $L$. saccharina and Alaria esculenta were counted and measured along the transect of known area by divers, with the aid of "fish rakes" (described by Fager et al., 1966). For pur- poses of comparison, the number of phaeophytes counted at each station has been standardized to equal plant counts for a $60 \mathrm{~m}^{2}$ survey area. The number of plants was rounded to the nearest whole number. The actual survey areas covered ranged from 54.1 to $69.4 \mathrm{~m}^{2}$. Divers noted the number of blade segments on larger plants to determine the minimum age (Dunton et al., 1982). The substrate and indications of ice scour were also described. All observations and identifications were made in situ.

During the August survey, two 0.63-mm, square-mesh rectangular baskets were positioned on the bottom between stations 2-4 and 3-4 with their open ends facing the predominant current (NE to $\mathrm{SW}$ ) to collect drifting kelp. Basket dimensions were $1.8 \mathrm{~m}$ along the bottom of the open end, $1 \mathrm{~m}$ high and $1 \mathrm{~m}$ deep. Both baskets were inspected by divers on 21 August, after basket 1 and basket 2 had collected for 7 and 26 days respectively. The contents of the baskets were identified and counted.

\section{RESULTS}

Three species of phaeophytes occur offshore of Prudhoe Bay. Laminaria solidungula and $L$. saccharina are common. Alaria esculenta occurs infrequently. 
The results of winter circular transects (Table 1) indicated that the density of kelp increased from 0.03 plants $\cdot \mathrm{m}^{-2}$ to 0.06 plants $\cdot \mathrm{m}^{-2}$ as water depth increased from 3.9 to $5.2 \mathrm{~m}$, and doubled again to 0.12 plants $\cdot \mathrm{m}^{-2}$ at a depth of $5.7 \mathrm{~m}$. There was a higher density, $0.12-0.23$ plants $\cdot \mathrm{m}^{-2}$, among the deeper $(5.7-6.2 \mathrm{~m})$ stations. The patches were more densely occupied, with a range of 6-30 plants $\cdot \mathrm{m}^{-2}$. Approximately onehalf of the plants were attached to the substrate.

TABLE 1. Density of kelp in the Beaufort Sea near Prudhoe Bay, Alaska (March and April 1979)

\begin{tabular}{cclcc}
\hline \hline Location & $\begin{array}{c}\text { Depth } \\
(\mathrm{m})\end{array}$ & Month & $\begin{array}{c}\text { Total Plants } \\
(\mathrm{N})\end{array}$ & $\begin{array}{c}\text { Kelp Plants } \\
\left(\text { per } \mathrm{m}^{2}\right)\end{array}$ \\
\hline 1 & 3.9 & $\begin{array}{l}\text { March } \\
\text { April }\end{array}$ & 10 & 0.03 \\
& & & 11 & 0.03 \\
2 & 5.2 & $\begin{array}{l}\text { March } \\
\text { April }\end{array}$ & 82 & 0.06 \\
& & March & 140 & 0.06 \\
3 & 6.2 & April & 159 & 0.11 \\
& & March & 180 & 0.13 \\
4 & 6.2 & April & 288 & 0.14 \\
& & & & 0.23 \\
5 & 6.6 & March & 185 & 0.15 \\
& & April & 197 & 0.16 \\
6 & & March & 177 & 0.14 \\
& 5.7 & April & 150 & 0.12 \\
\hline
\end{tabular}

Density of phaeophytes at each August survey station is shown in Table 2, with average densities with depth, and along an east-west gradient. A more dense band of kelp (0.97-1.27 plants $\cdot \mathrm{m}^{-2}$ ) existed at depths of 5.5-7.3 $\mathrm{m}$ than at shallower or deeper stations. An east-west density gradient was not apparent. The highest mean density occurred in transect $5(10.4$ plants $\cdot \mathrm{m}^{-2}$ ) to the far east, and the second highest in transect 1 $\left(0.89\right.$ plants $\left.\cdot \mathrm{m}^{-2}\right)$ to the far west.

Attached plants give a better indication of how much kelp is

TABLE 2. Density of Laminaria (number of plants $\cdot \mathrm{m}_{-}^{-2}$ ) observed offshore of Prudhoe Bay, Alaska - August 1979

\begin{tabular}{|c|c|c|c|c|c|c|}
\hline \multicolumn{7}{|c|}{ Transect Number } \\
\hline $\begin{array}{l}\text { Depth } \\
\text { (Metres) }\end{array}$ & $\begin{array}{c}\text { West } \\
1\end{array}$ & 2 & $\begin{array}{c}\text { to } \\
3 \\
\end{array}$ & 4 & $\begin{array}{c}\text { East } \\
5 \\
\end{array}$ & $\begin{array}{c}\text { Mean } \\
\text { Density }\end{array}$ \\
\hline 3.0 & & & 0.16 & & & 0.16 \\
\hline 4.0 & & 0.70 & & 0.21 & 0.08 & 0.33 \\
\hline 4.6 & & & 0.36 & & & 0.36 \\
\hline 5.2 & & & & 0.02 & & 0.02 \\
\hline 5.5 & & 1.11 & & & & 1.10 \\
\hline 6.1 & 1.66 & & & 0.46 & & 1.06 \\
\hline 6.7 & & & & & 0.97 & 0.97 \\
\hline 7.3 & & & 0.47 & & 2.07 & 1.27 \\
\hline 7.6 & & & 0.28 & 0.61 & & 0.42 \\
\hline 8.2 & & 0.10 & & & & 0.10 \\
\hline 9.4 & & 0.03 & & & & 0.03 \\
\hline 10.1 & 0.11 & & & & & 0.11 \\
\hline Mean & 0.89 & 0.49 & 0.32 & 0.33 & 1.04 & \\
\hline
\end{tabular}

relatively permanent at each station, since unattached plants are more prone to drifting when currents are present. Kelp attached to the substrate made up $47 \%$ of the kelp plants surveyed in August (Table 3). An increase in mean density (0.28-10.4 plants $\left.\cdot \mathrm{m}^{-2}\right)$ was again apparent at $5.5-7.3 \mathrm{~m}$ depths (Table 3). Mean densities at shallower and deeper stations were $0.0-0.19$ plants $\cdot \mathrm{m}^{-2}$. Comparing densities from east to west, transect 5 had the highest mean density $(0.65$ plants $\cdot \mathrm{m}^{-2}$ ). Station 5-1 was in the Stefansson Sound kelp community and stations 5-2 and 5-3 bordered this area. Transects $1,2,3$ and 4 all showed mean densities of 0.17 . The substrate over transects $1,2,3$ and 4 was loose silt and sand except at station 4-1, where the substrate was very coarse sand and gravel. Station 4-1 was heavily scoured by icebergs, which was apparent from the absence or near-absence of siltation and frequent criss-crossing gouges throughout the area. Ice scour was present at all other stations but was not nearly as severe.

TABLE 3. Density of attached Laminaria (number of plants $\cdot \mathrm{m}^{-2}$ ) observed offshore of Prudhoe Bay, Alaska - August 1979

\begin{tabular}{|c|c|c|c|c|c|c|}
\hline \multicolumn{7}{|c|}{ Transect Number } \\
\hline $\begin{array}{l}\text { Depth } \\
\text { (Metres) }\end{array}$ & $\begin{array}{c}\text { West } \\
1\end{array}$ & 2 & $\begin{array}{c}\text { to } \\
3 \\
\end{array}$ & 4 & $\begin{array}{c}\text { East } \\
5\end{array}$ & $\begin{array}{c}\text { Mean } \\
\text { Density }\end{array}$ \\
\hline $\begin{array}{r}3.0 \\
4.0 \\
4.6 \\
5.2 \\
5.5 \\
6.1 \\
6.7 \\
7.3 \\
7.6 \\
8.2 \\
9.4 \\
10.1 \\
\end{array}$ & 0.28 & $\begin{array}{l}0.02 \\
0.03\end{array}$ & $\begin{array}{l}0.07 \\
0.02\end{array}$ & $\begin{array}{l}0.11 \\
0.00 \\
0.33\end{array}$ & $\begin{array}{l}0.28 \\
1.66\end{array}$ & $\begin{array}{l}0.07 \\
0.12 \\
0.02 \\
0.00 \\
0.39 \\
0.31 \\
0.28 \\
1.04 \\
0.19 \\
0.02 \\
0.03 \\
0.05 \\
\end{array}$ \\
\hline Mean & 0.17 & 0.17 & 0.17 & 0.17 & 0.65 & \\
\hline $\begin{array}{l}\text { Percent } \\
\text { Attached }\end{array}$ & $18 \%$ & $35 \%$ & $51 \%$ & $52 \%$ & $62 \%$ & \\
\hline
\end{tabular}

Approximately $80 \%$ of the attached kelp in the summer survey was Laminaria solidungula. Laminaria saccharina constituted approximately $20 \%$ of all attached kelp in the summer survey, or $28 \%$ of all attached kelp if station 5-1, which has a much higher percentage of rocky substrate, is excluded. Attached Alaria esculenta was only found at stations $2-3$ and $2-4$ in the summer survey.

Most of the plants had two and three years of growth intact on the fronds; one had four years of growth. All larger plants had sloughed older tissue from the tips of their fronds. Individuals of all three species were found with total lengths surpassing $200 \mathrm{~cm}$. Most plants measured $30-120 \mathrm{~cm}$ in length.

The drifting-kelp baskets were examined after 7 and 29 days, and counts were made of 27 and 57 plants respectively.

\section{DISCUSSION}

Our study attempted to determine the distribution and abun- 
dance of phaeophytes offshore of Prudhoe Bay. Winter results showed that kelp occurred in 3.9-6.6 m depths. Concentrated phaeophytes (patches) were found at 5.7-6.6 m depths. Summer results indicated that higher densities of phaeophytes occurred in 5.5-7.3 m of water. Dunton and Schonberg (1980) reported macrophytes growing at 5-8 $\mathrm{m}$ depths in Stefansson Sound.

Laminaria solidungula were observed attached to rocks, pebbles and shells by a means of a discoidal holdfast. Several L. solidungula were often found attached to infrequently occurring fist-sized rocks. Laminaria saccharina and Alaria esculenta seem better fitted for growth on easily disturbed substrates. Laminaria saccharina found at station 5-1, an area with many rocks and small boulders, were not attached to these likely surfaces but had secured their holdfasts in the outlying areas of sand or silt. They were more numerous in depressions and areas below ledges at all stations surveyed. A $5-\mathrm{m}^{2}$ pile of cement, apparently unused and dumped from a boat, was found near station 2-3. No macrophytes had settled on the cement; however, there were $20 \mathrm{~L}$. saccharina with holdfasts buried in the, silt beside and underneath the cement.

The average density of macrophytes over sand and silt substrates is substantially lower than macrophyte densities within Stefansson Sound (Dunton and Schonberg, 1980). Lower densities over Prudhoe Bay are probably a result of less favorable substrate. The small macrophyte patches observed in our winter surveys appeared visually to be as dense as areas of heavy phaeophyte concentrations at station 5-1. Most of the sand and silt substrate offshore of Prudhoe Bay appears to be able to support a low density of macrophytes overall but approaches plant densities of rocky substrate in very small areas. Chapman (1944) characterized L. saccharina as growing in areas of shingle and small stones and in sandy bays where it is attached to stones partially buried in the sand. Ellis and Wilce (1961) reported drift Laminariaceae on mud and sand bottoms in arctic Canada. Lee (1973) infrequently found drift and in situ growth of several species of benthic algae on clay and silt in arctic Canada.

Kelp drifts primarily during the open water season. Current meters moored near station 2-4 from February through April measured current speeds below $5 \mathrm{~cm} \cdot \mathrm{sec}^{-1} 99 \%$ of the time (Mangarella et al., 1979). Current meters recorded speeds $<20 \mathrm{~cm} \cdot \mathrm{sec}^{-1}$ over $90 \%$ of the time with maximum velocities of $35 \mathrm{~cm} \cdot \mathrm{sec}^{-1}$ during August of 1978 and 1979 (Chin et al., 1979; Chin, 1979). As the currents are wind-generated, a complete reversal of current direction can occur in less than one day (Mangarella et al., 1982).

The Stefansson Sound kelp community has been described by Dunton et al. (1982) as a unique habitat in the Beaufort Sea. The contribution of phaeophytes from Stefansson Sound to the adjacent waters of Prudhoe Bay must be considered in any study of kelp distribution in this area. We expected to see a decreasing density gradient of attached and unattached phaeophytes west of Stefansson Sound if drifting phaeophytes from this area were responsible for the Prudhoe Bay flora. Similar average densities for transects 1 through 4 of 0.17 attached plants $\cdot \mathrm{m}^{-2}$ might suggest that phaeophytes in the study area maintain their numbers independently of the Stefansson Sound kelp community. The data in Table 2 show that the total number of phaeophytes was greatest in the area of the Stefansson Sound kelp community but do not show a diminishing density gradient to the west of Stefansson Sound from transect 5 to transect 1 .

Although the distance between transects 1 and 5 is large (26 $\mathrm{km}$ ), it may not be large enough to show a density gradient, should one exist. Additionally, all of this survey was done west of the Boulder Patch. As noted above, current direction changes during the open-water months, implying a zone of influence to the east as well. If the Boulder Patch is the source of the kelp in the region, either as sporophytes or as full-size drifting plants (few juvenile plants were recorded in this survey), the western component of the Boulder Patch sphere of influence may be much larger than the area of this study.

If the limiting factor in kelp distribution is suitable substrate, and if sufficient numbers of colonizers are generated, no density gradient would be expected with distance from the Boulder Patch. All available substrate would be colonized. Numbers of plants sufficient to generate these colonizers may or may not exist outside of the Boulder Patch.

The importance of phaeophytes as a substrate of other algae and sessile fauna, as an ever-present source of primary production and possibly as a microhabitat, has not been determined. Dunton and Schonberg $(1979,1980)$ have shown exceptionally high faunal diversity and biomass associated with Stefansson Sound macrophytes. Our preliminary observations also indicated an increase in faunal diversity in areas of high phaeophyte densities (Beehler et al., 1979a, 1979b). Macrophytes may exist over additional areas of the coastal Alaskan Arctic in sufficient numbers to affect faunal diversity and biomass.

\section{ACKNOWLEDGEMENTS}

These data were collected under the sponsorship of the owner companies of the Prudhoe Bay Unit and with the assistance of personnel from ARCO Alaska. We would like to thank Ken Dunton, Erk Reimnitz, Helmut Koch and Carter Broad for our various discussions on kelp, benthos and the habitats of the Beaufort Sea.

\section{REFERENCES}

BUREAU OF LAND MANAGEMENT. 1979. Beaufort Sea final environmental impact statement. Vol. 1. Anchorage, Alaska: Bureau of Land Management. $397 \mathrm{p}$.

BEEHLER, C., BUSDOSH, M., TARBOX, K., and ROBILLIARD. G. 1979a. Occurrence of kelp offshore of Prudhoe Bay, Alaska. In: Environmental Studies of the Beaufort Sea - Winter 1979. Report prepared for Prudhoe Bay Unit by Woodward-Clyde Consultants. 1-36.

1979b. Distribution and abundance of kelp offshore of Prudhoe Bay in August 1979. In: Environmental Studies of the Beaufort Sea - Summer 1979. Report prepared for Prudhoe Bay Unit by Woodward-Clyde Consultants. Ch. 3:1-61.

BROAD, A.C. 1978. Reconnaissance characteristics of littoral biota, Beaufort and Chukchi Seas. Environmental Assessment of the Alaskan Cuntinental Shelf. Vol. V. October 1978. 182 p.

CHAPMAN, V.J. 1944. Methods of surveying Laminaria beds. Journal of the Marine Biological Association of the United Kingdom 26:37-60. 
CHIN, H. 1979. Physical/Chemical measurements taken in the Beaufort Sea - July/August 1979. In: Environmental Studies of the Beaufort Sea Summer 1979. Report prepared for Prudhoe Bay Unit by WoodwardClyde Consultants. Ch. 5:1-95.

BUSDOSH, M., ROBILLIARD, G.A., and FIRTH, R.W. 1979. Environmental studies associated with the Prudhoe Bay dock: Physical oceanography and benthic ecology. Woodward-Clyde Consultants Final Report to ARCO Oil and Gas Company. 228 p.

DUNTON, K. 1979. Diving for kelp in the Arctic. Alaska magazine XLV(7) July.

REIMNITZ, E., and SCHONBERG, S. 1982. An arctic kelp community in the Alaskan Beaufort Sea. Arctic 36(4):465-484.

DUNTON, K., and SCHONBERG, S. 1979. An arctic kelp community in Stefansson Sound, Alaska; a survey of the flora and fauna. In: Broad, A.C. (ed.). Reconnaissance Characterization of Littoral Biota, Beaufort and Chukchi Seas. OSCEAP. Vol. V:

1980. Ecology of the Stefansson Sound kelp community: Preliminary results of in situ and benthic studies. In: Broad, A.C. et al. (eds.). Environmental Assessment of Selected Habitats in Arctic littoral systems. OCSEAP. Vol. VI:

ELLIS, D.V., and WILCE, R.T. 1961. Arctic and subarctic examples of intertidal zonation. Arctic 14(4):224-235.

FAGER, E.W., FLECHSIG, A.D., FORD, R.F., and DAWSON, E.Y. 1966. Equipment for use in ecological studies using SCUBA. Limnology \& Oceanography 11(4):503-509.

LEE, R.K. 1973. General ecology of the Canadian Arctic benthic marine algae. Arctic 26(1):32-43.

1980. A catalogue of the marine algae of the Canadian Arctic. Ottawa: National Museum of Canada Publications in Botany 9.

MANGARELLA, P., CHIN, H., and NIEDORODA, A. 1979. Under-ice water conditions in the Beaufort Sea relative to the proposed Waterflood discharge. In: Environmental studies of the Beaufort Sea - Winter 1979. Report prepared for Prudhoe Bay Unit by Woodward-Clyde Consultants. Ch. 1:1-252.

MANGARELLA, P.A., HARPER, J.R., and WEINGARTNER, T.J. 1982. Prudhoe Bay waterflood project physical processes monitoring program. Appendix A. Anchorage, Alaska: U.S. Army Corps of Engineers. 123 p.

MOHR, J.L., WILIMOVSKY, N.J., and DAWSON, E.Y. 1957. An arctic Alaskan kelp bed. Arctic 19:45-54.

TARBOX, K., and SPIGHT, T. 1979. Beaufort Sea fishery investigations. In: Biological effects of impingement and entrainment from operation of the proposed intake. Report to Prudhoe Bay Unit by Woodward-Clyde Consultants. $42 \mathrm{p}$. 